\title{
Ocean climate and EI Niño impacts on survival of Cassin's Auklets from upwelling and downwelling domains of British Columbia
}

\author{
Douglas F. Bertram, Anne Harfenist, and Barry D. Smith
}

\begin{abstract}
We report on the survival of populations of Cassin's Auklet (Ptychoramphus aleuticus) that breed on two oceanic colonies in British Columbia: Triangle Island, near the northern end of the California Current Ecosystem, and Frederick Island to the north in the Alaska Current Ecosystem. We captured and banded birds at both colonies from 1994 to 2000 and analyzed the recovery data with the computer program MARK. Average local adult annual survival ( \pm standard error) was significantly lower $(p=0.0001)$ on Triangle Island $(0.71 \pm 0.02)$ than that on Frederick Island $(0.80 \pm 0.02)$, likely a result of poor production in the California Current Ecosystem during the 1990s. Coincident with a strong El Niño event, survival in 1997-1998 fell in unison to the lowest values observed for both colonies (to $0.54 \pm 0.05$ and $0.64 \pm 0.04$, respectively, for adults). A common winter environment in the California Current Ecosystem could explain the unified mortality response of both British Columbia populations to an exceptionally poor food period. The seabird colonies in this study occupy key positions in relation to major oceanographic domains and hence provide unique platforms for investigations of marine ecosystem response to ocean climate variability in the Northeast Pacific Ocean.
\end{abstract}

\begin{abstract}
Résumé : Notre étude traite de la survie des stariques de Cassin (Ptychoramphus aleuticus) qui se reproduisent dans deux colonies océaniques de la Colombie-Britannique, à l'île Triangle, près de l'extrémité nord de l'écosystème du courant de la Californie et à l'île Frederick, plus au nord dans l'écosystème du courant de l'Alaska. Nous avons capturé des oiseaux dans les deux colonies de 1994 à 2000 et les avons munis de bagues; nous avons analysé les données de recapture à l'aide du logiciel MARK. La survie annuelle moyenne locale ( \pm erreur type) est significativement plus faible $(p=0,0001)$ à l'île Triangle $(0,71 \pm 0,02)$ qu'à l'île Frederick $(0,80 \pm 0,02)$, probablement à cause de la production réduite dans l'écosystème du courant de la Californie dans les années 1990. Durant un important événement El Niño en 1997-1998, la survie est tombée simultanément au niveau le plus bas observé dans les deux colonies (respectivement à $0,54 \pm 0,05$ et $0,64 \pm 0,04$ chez les adultes). Un environnement commun en hiver dans l'écosystème du courant de la Californie pourrait expliquer la réaction semblable de mortalité dans les deux populations de la ColombieBritannique en réponse à une période exceptionnellement pauvre en nourriture. Les colonies d'oiseaux de mer de cette étude sont dans des positions clés par rapport aux domaines océaniques majeurs et elles fournissent donc des « platesformes » exceptionnelles pour étudier la réaction des écosystèmes marins à la variabilité du climat océanique dans le nord-est du Pacifique.
\end{abstract}

[Traduit par la Rédaction]

\section{Introduction}

Recent climate variability in the Northeast Pacific Ocean has had major impacts on biological production and marine populations. During the warm phase of the Pacific Decadal Oscillation (a long-lived, El Niño-like pattern of Pacific cli- mate variability; Mantua 2000; Mantua and Hare 2002), production of salmonids showed inverse patterns latitudinally, with poor production in the California Current Ecosystem and enhanced production in the Alaska Current Ecosystem (e.g., Hare et al. 1999; Botsford and Lawrence 2002). As upper trophic level predators, seabird populations in the Cali-

Received 21 September 2004. Accepted 11 July 2005. Published on the NRC Research Press Web site at http://cjfas.nrc.ca on 8 November 2005.

J18318

D.F. Bertram. ${ }^{1,2}$ Simon Fraser University, Centre for Wildlife Ecology, Department of Biological Sciences,

8888 University Drive, Burnaby, BC V5A 1S6, Canada, and Environment Canada, Canadian Wildlife Service,

5421 Robertson Road, Delta, BC V4K 3N2, Canada.

A. Harfenist ${ }^{3}$ and B.D. Smith. Environment Canada, Canadian Wildlife Service, 5421 Robertson Road, Delta, BC

V4K 3N2, Canada.

${ }^{1}$ Corresponding author (e-mail: bertramd@pac.dfo-mpo.gc.ca).

${ }^{2}$ Present address: Environment Canada, Canadian Wildlife Service, c/o Institute of Ocean Sciences, 9860 West Saanich Road, P.O. Box 6000, Sidney, BC V8L 4B2, Canada.

${ }^{3}$ Present address: Harfenist Environmental Consulting, P.O. Box 2498, Smithers, BC V0J 2N0, Canada. 
fornia Current have also reflected the recent warm ocean climate through negative impacts on survival (Bertram et al. 2000) and reproduction (Bertram et al. 2001; Gjerdrum et al. 2003; Abraham and Sydeman 2004). Indeed, seabirds are being increasingly recognized as a useful biological indicator and bellwether for marine ecosystem climate variability (Barbraud and Weimerskirch 2001; Boyd and Murray 2001) because of the breadth and variety of information that studies on seabirds can reveal. Most seabirds spend over $90 \%$ of their lives on the ocean and come ashore only to breed. Colony-based studies can provide estimates of timing of breeding, breeding effort, nesting performance (hatch and fledging success), and nestling growth and diet and can reveal insights about local production and marine community composition (e.g., Bertram et al. 2001). In addition, capturemark-recapture (CMR) programs on colonies can yield information on age-specific annual survival, because seabirds are iteroparous, long-lived, tenacious to breeding colonies and nesting locations, and they can be individually marked. Because seabirds are migratory, variation in adult annual survival measured at the nesting colony may also reflect conditions at wintering areas that are distant from the breeding grounds. Gaston (2003) has reported that population changes may be determined by events on common wintering grounds for temperate and arctic populations of Thick-billed Murres (Uria lomvia). Opportunities for insights into seabird population dynamics in response to changes in marine ecosystems are heightened during extreme periods, such as the El Niño - La Niña event of 1997-1998. During the warm phase of the Pacific Decadal Oscillation and prolonged El Niño-like conditions during the 1990s (Trenbeth and Hoar 1996), surface waters in the California Current were anomalously warm, and sea surface temperatures peaked in 1998 during the 1997-1998 El Niño. Ocean temperatures cooled dramatically in 1999 coincident with the La Niña and a suspected regime shift to the cold phase of the Pacific Decadal Oscillation. Here we report on the impacts of ocean climate variability and the extreme events of the 1997-1998 El Niño (see Wolter and Timlin 1998) on two seabird populations in British Columbia (BC) with distinctly different oceanographic influences.

Within the Northeast Pacific Ocean, BC occupies a pivotal position from an oceanographic perspective, because the North Pacific Current (also called the West Wind Drift) bifurcates off its coast, forming the Alaska Current to the north and the California Current to the south. Associated with these major currents, $\mathrm{BC}$ has three oceanographic domains: the downwelling domain in the north, the upwelling domain in the south, and the transitional domain in the central coast (Ware and McFarlane 1989, Fig. 1). Queen Charlotte Sound, in the transitional domain, also provides an obstacle to poleward transport of water by disrupting the effectively continuous coastline that extends from central California to the northern tip of Vancouver Island.

BC supports large populations of colonial seabirds, including 75\% of the world's Cassin's Auklet (Ptychoramphus aleuticus; Manuwal and Thoreson 1993) population, a largely planktivorous member of the family Alcidae, with breeding colonies widely separated by latitude. Cassin's Auklets are small seabirds $(\sim 180 \mathrm{~g})$ that use their wings for flying and for propulsion underwater in search of prey. A Cassin's Auklet's maximum dive depth averaged $22 \mathrm{~m}$ with a mode of $40 \mathrm{~m}$ in a study at Reef Island, BC (Burger and Powell 1989). Seabirds tend to exhibit strong natal philopatry and breed at colonies from which they were hatched. Like most seabirds, Cassin's Auklets have long lives, delayed maturity, and low reproductive output (females usually lay a single egg per year on colonies in BC). Birds use underground burrows for nesting and only arrive and depart from the colony during darkness. The nestling is fed regurgitations each night from both parents, who carry food in a gular pouch. Foraging distances for breeders may be colony specific, with parents typically foraging within $30 \mathrm{~km}$ of Prince Island in California (Adams et al. 2004) and between 40 and $75 \mathrm{~km}$ from the colony on Triangle Island in BC (e.g., Boyd et al. 2000; Ryder et al. 2001). After the breeding season (March-July in BC), the birds migrate, leaving the colonies to return the following spring. Information on the marine areas used by BC's Cassin's Auklets during the nonbreeding season is extremely limited, but Campbell et al. (1990) and also Connie Smith (Simon Fraser University, Department of Biological Sciences, 8888 University Road, Burnaby, BC V5A IS6, unpublished data) indicate that the birds winter along the Pacific Coast between southern Vancouver Island and Baja, California.

We report on differences in annual adult survival for Cassin's Auklet populations at two colonies in key positions with respect to the major currents and oceanographic domains within BC: Triangle Island at the northern end of the California Current in the upwelling domain and Frederick Island, influenced by the Alaska Current, in the coastal downwelling domain of BC (Fig. 1). The timing of the study (1994-2000) facilitated an additional natural experiment, because it allowed us to investigate the survival impacts of a major El Niño event during 1997-1998 on the two seabird populations. The contrast is interesting because despite distinct breeding colonies, the populations are migratory and both may winter at southerly locations in the California Current Ecosystem and thus share common marine environmental effects for part of the annual cycle. Finally, we discuss the utility for including seabird demographics in state-ofocean investigations and reporting.

\section{Materials and methods}

\section{Study sites}

The study sites are among the outermost western islands on the coast of BC in the Pacific Ocean near the continental shelf break, but are influenced by different oceanographic domains (Fig. 1). Triangle Island $\left(51^{\circ} 52^{\prime} \mathrm{N}, 129^{\circ} 05^{\prime} \mathrm{W}\right)$, the largest seabird colony in BC and the largest Cassin's Auklet colony in the world (540000 breeding pairs in 1989; Rodway et al. 1990), is windswept and effectively treeless as the outermost island of the Scott Island chain off the northern tip of Vancouver Island. The flora and fauna of the island have been described by Carl et al. (1951). The island is protected as an ecological reserve by the province of $\mathrm{BC}$. Triangle Island was visited in all years 1994 to 2000.

Frederick Island $\left(53^{\circ} 56^{\prime} \mathrm{N}, 133^{\circ} 11^{\prime} \mathrm{W}\right)$ lies approximately $2 \mathrm{~km}$ off the northwest coast of Haida Gwaii (Queen Char- 
Fig. 1. Study sites showing major oceanographic domains and currents in British Columbia (after Ware and McFarlane 1989). Note that the north-south location of the bifurcation of the North Pacific Current can vary between years (Freeland and Cummins 2005).

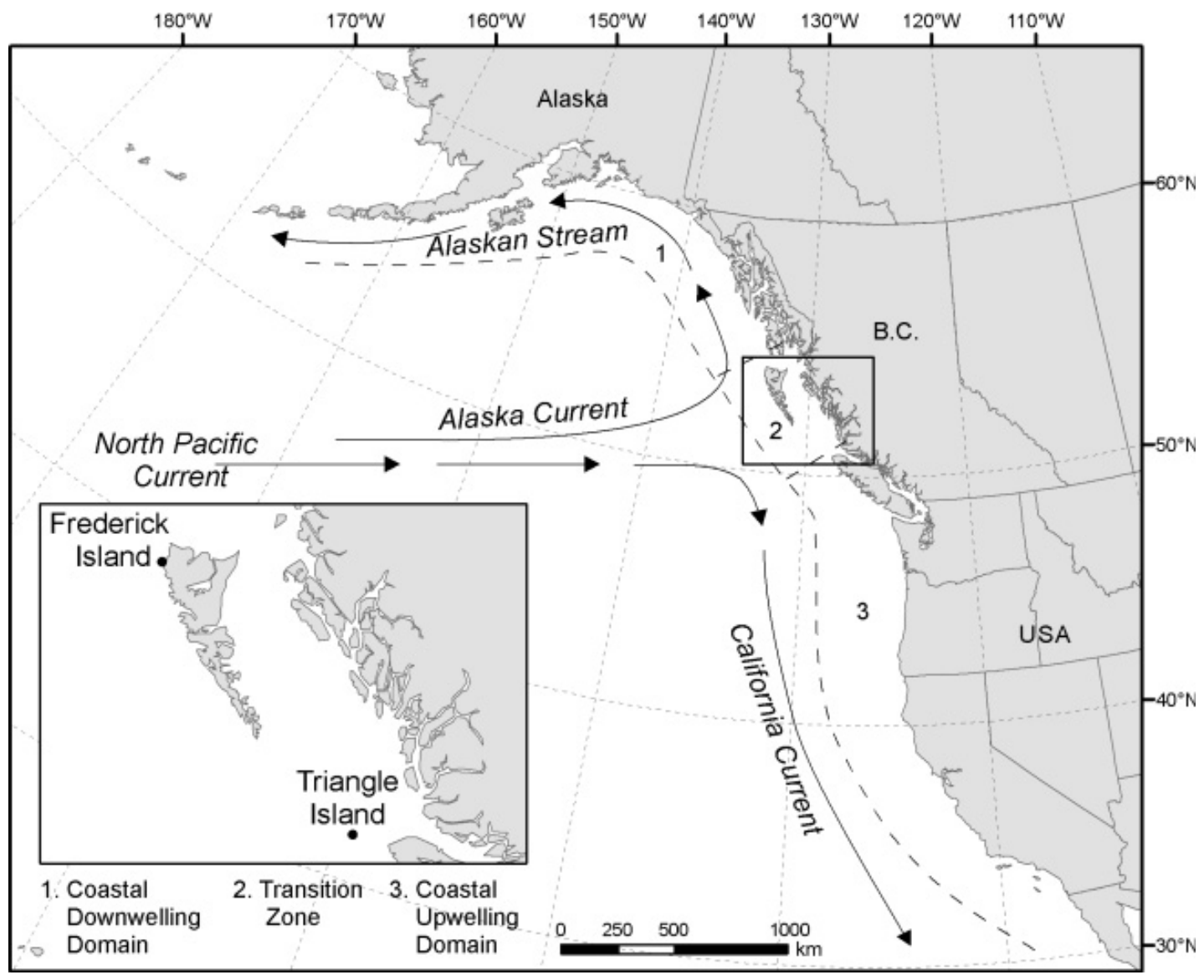

lotte Islands). The colony had approximately 90000 pairs of nesting Cassin's Auklets in 1980 (Rodway 1991). Frederick Island was visited in 1994-1998 and 2000. Frederick Island is largely forested; the vegetation is described in Rodway et al. (1994). The island is protected as a wildlife habitat area by the province of $\mathrm{BC}$.

Cassin's Auklets were captured using barrier nets $(5 \mathrm{~cm} \times$ $5 \mathrm{~cm}$ multistrand plastic mesh) set at the base of nesting slopes (Triangle Island) or along the beach parallel to the edge of nesting areas (Frederick Island). Two trapping sites were used on each island. The sites were topographically isolated from each other and from sites of other concurrent studies (reproduction, diet, mate and site fidelity) on the islands, and no Cassin's Auklet banded in those other studies was caught in the traps. On Triangle Island, the net length and height were approximately $15 \mathrm{~m} \times 3 \mathrm{~m}$ in West Bay and $20 \mathrm{~m} \times 3 \mathrm{~m}$ in Calamity Cove. On Frederick Island, the Camp Bay net was approximately $40 \mathrm{~m} \times 7.5 \mathrm{~m}$, and the North Beach net was about $50 \mathrm{~m} \times 8.5 \mathrm{~m}$. Trapping was conducted from April to July on Triangle Island and from May to July on Frederick Island. We minimized disturbance to birds by trapping birds as they departed from the colony during the early morning after most arrivals had ceased. Nets were set between 0200 and 0500 on Triangle Island and from 0200 to 0530 or $15 \mathrm{~min}$ after the last bird was caught, whichever was later, on Frederick Island. Nets were set for 6-8 mornings at each site in each year on Frederick Island and for 10-20 mornings at each site on Triangle Island. We banded each bird caught with a United States Fish and Wildlife Service stainless steel band and scored iris colour based on modifications of the technique of Manuwal (1978; see below). On Frederick Island, most birds were released within 2 min of hitting the net. On Triangle Island, birds were measured and usually released within 2-20 min.

\section{Burrow occupancy}

To estimate breeding activity, we examined a sample of burrows each year for occupancy (presence of an egg, chick, or adult). Occupancy determinations were made throughout the incubation period on Triangle Island and during late incubation on Frederick Island coincident with the arrival of the field crew. When burrows were clearly defunct, new burrows were added to the sample. Our comparisons focused on differences between years within a colony rather than intercolony contrasts in burrow occupancy.

\section{CMR analysis}

We prepared our banded bird resighting data from 1994 to 2000 for analyses of survival rates by the computer program MARK (White and Burnham 1999). Survival is an annual rate presumed to span the 365 days from the middle of the breeding period (approximately 15 May) in consecutive years. We cannot distinguish between breeding season and overwintering mortality, since the number of repeated sightings 
of individuals in the short, spring breeding season was insufficient to calculate a meaningful survival rate. Survival was estimated using the Cormack-Jolly-Seber (CJS) model for marked individuals recaptured sequentially in time. Our intention to discriminate survival rates by location, age, and year, including the possible influence of an El Niño year, required that our data preparation consider three attributes of each Cassin's Auklet. For each Cassin's Auklet marked and recaptured, we recorded the location (trap site and island), the year, and the Cassin's Auklet's eye colour. Though the number of multiply recaptured birds was insufficient for breeding season survival analyses, these recaptures proved valuable for assessing the in-season reliability of eye colour assessments (see Appendix A).

Eye colour is a known index of Cassin's Auklet maturity, with iris colour evolving from brown, through mixed brown and white (which we term intermediate), then eventually to white as a Cassin's Auklet ages (Manuwal 1978; Emslie et al. 1990). However, eye colour is an imperfect index of age due to variability in the rate at which individual Cassin's Auklets progress from brown to white. Additionally, data accuracy is potentially complicated by the need to use a headlamp as a light source, which causes changes to pupil size and can make iris colour difficult to determine. To minimize measurement uncertainty in our assessment of eye colour, we recorded as many as six and four gradients in eye colour on Triangle and Frederick Islands, respectively, then later compressed these variants into the three less uncertain categories of brown, brown-white (intermediate), or white. Eye colour was easiest to score for white and brown-eyed birds and was most uncertain for the intermediate stages. We developed confidence that eye colour was a meaningful measure of Cassin's Auklet maturity and age by carefully following eye colour changes within and between seasons at both Triangle and Frederick islands (Appendix A).

Despite the need for caution when interpreting the intermediate eye colour category as a measure of age progression (see Results), we structured our CJS analysis on the premise that the eye colour of a Cassin's Auklet when it was first marked defined its age category at that time. We retained confidence in this protocol because our data strongly indicated that the duration of the intermediate eye colour was, on average, about 1 year (Appendix A). Thus for each of the two sites $(s)$ on each of the two islands $(i)$, our CJS analysis comprised three groups $(g=1,2, \mathrm{~A})$, each corresponding to eye colour at initial marking, resulting in a total of 12 groups. We then defined the corresponding age-structured, local survival rates, for first-year ( $a=1$, brown-eyed), second-year ( $a=2$, intermediate), and adult ( $a=\mathrm{A}$, white-eyed) birds, where local survival includes survivorship from both mortality and dispersal. Parameter matrices for each group were constructed to reflect this age progression and allow annual survival rates to differ among years $(y, 1994 \rightarrow 1995$ until $1999 \rightarrow 2000)$. Additionally, local survival rates for the firstyear postmarking $(m=1)$, were allowed to differ from all later $(m=\mathrm{L})$ annual local survival rates. This design feature allowed parametric distinction between estimates of local survival rates for birds that never returned the year after being marked (our so-called transients or prospectors) and estimates that measured survival of birds that returned at least once after having been marked (our so-called residents). We cannot interpret whether birds that never returned died or dispersed to other populations. We represent local survival $(\phi)$ and recapture probability $(p)$ as thus $\phi_{i, g, m, a, y}$ and $p_{i, g, m, a, y}$.

As previously stated, no sampling on Frederick Island (F) was conducted during 1999, such that the recapture probability for 1999 is zero $\left(p_{\mathrm{F}, g, m, a, 1999}=0\right)$. We compensated for this missed sampling year in our analyses by assuming survival at Frederick Island to be unity from $1998 \rightarrow 1999$ $\left(\phi_{\mathrm{F}, g, m, a, 1998 \rightarrow 1999}=1\right)$ then a posteriori interpreting the survival rates $\phi_{\mathrm{F}, g, m, a, 1998 \rightarrow 1999}$ and $\phi_{\mathrm{F}, g, m, a, 1999 \rightarrow 2000}$ to be identical as the square root of the estimate for $\phi_{\mathrm{F}, g, m, a, 1999 \rightarrow 2000}$.

Model parsimony was obtained by using a design matrix to minimize the potential number of model parameters (White and Burnham 1999). Preliminary analyses suggested similarities in the interannual patterns for $\phi$ among age classes for each island and site and similarities in the interannual patterns for $p$ among eye colour groups for each island. Our hypothetical model set thus posed two models for $p$ and three models for $\phi$. Given the satisfactory performance of our global model for survivorship described above $(\hat{\mathrm{c}} \approx$ 1.2), we thus limited our hypothesis concerning the vector of recapture probabilities, $p$, to two submodels: $(i)$ an identity design and (ii) annual $p$ s constrained to conform to similar patterns (pre-logit-transformation) for each group. Likewise, we limited our hypotheses concerning $\phi$ to four submodels: (i) a basic age-group structure but without a parametric accommodation for transient Cassin's Auklets, (ii) a basic agegroup structure, (iii) a basic age-group structure but with the $\phi$ s constrained to conform to similar patterns (pre-logittransformation) for each group, and (iv) model iii but allowing the El Niño year to vary independently for the adult $a=$ A age class.

Model selection protocols were followed as described in Burnham and Anderson (2002), with the best model (most parsimonious) being chosen on the basis of lowest Akaike's Information Criterion corrected over dispersion $\left(\mathrm{QAIC}_{\mathrm{c}}\right) . \mathrm{A}$ posteriori goodness-of-fit diagnostics (including the coefficient of overdispersion $\hat{c}$ ) were evaluated to assure our analyzed data were a satisfactory realization of the model we accepted.

\section{Results}

\section{Burrow occupancy 1994-2000}

Burrow occupancy was consistently lower on Triangle Island than on Frederick Island in all years of the study from 1994 to 1998 (Fig. 2). Between 1994 and 1997, occupancy did not vary appreciably, averaging around $85 \%$ on Frederick Island and $60 \%$ on Triangle Island. In 1998, burrow occupancy fell by $20 \%-30 \%$ on both colonies to the lowest values recorded. Burrow occupancy increased following the El Niño on both colonies.

\section{CMR analysis}

A total of 1483 (at the Calamity Cove site) and 2050 (at the West Bay site) Cassin's Auklets were banded at Triangle Island. At Frederick Island, 1614 (at the Camp Bay site) and 1394 (at the North Beach site) Cassin's Auklets were 
Fig. 2. Burrow occupancy (breeding propensity) on Triangle Island (triangles) and Frederick Island (squares). Note the drop in both colonies in 1998.

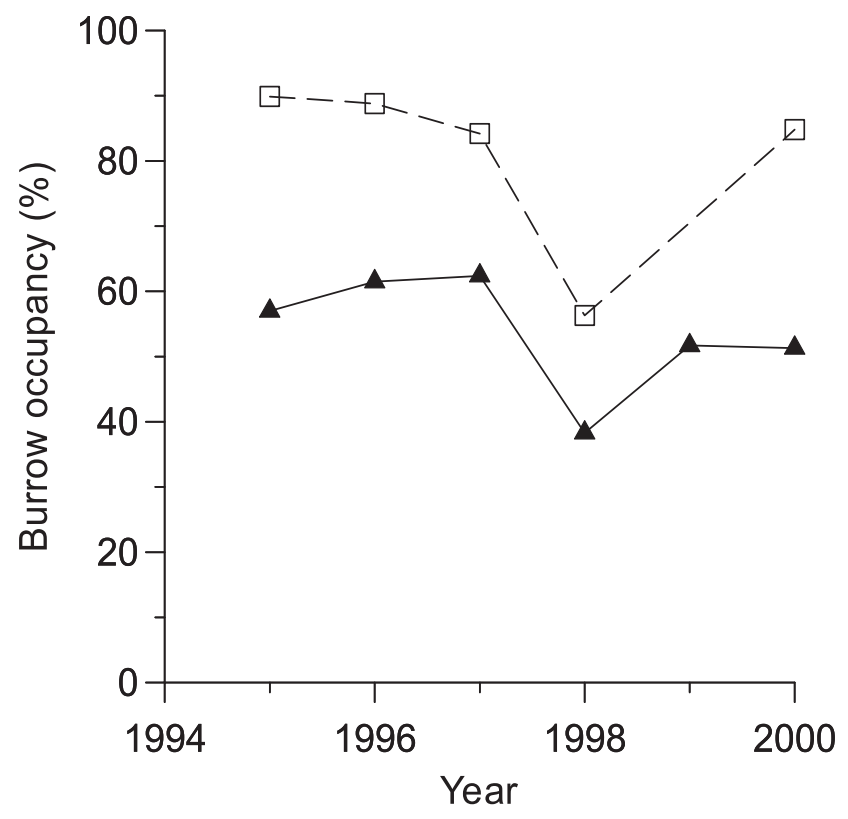

banded. Multiple recaptures within a year explain why fewer than these totals of birds contributed to the CMR analyses reported in Table 1.

\section{Model ranking}

Model ranking by $\mathrm{QAIC}_{\mathrm{c}}$ indicated that our best model (ranked 1st) supported three characteristics of our CMR data (Table 2). First, the phenomenon of having transient Cassin's Auklets that never returned to the particular site where they were marked was statistically validated. However, they may have returned to elsewhere on the island where they were marked. Second, there was a clear increase in the local survival rate as Cassin's Auklets aged. Third, there was support for the idea that interannual variability in survival was modulated similarly among the three age categories, with the exception of the El Niño year (Figs. 3 and 4; Table 3). Though there were unique features associated with each island, the general patterns of survivorship noted above pertained to both sites on both islands.

The complexity of the design matrix for the best model (1st ranked) tends to disguise the overall difference in survival rate between Frederick and Triangle islands because survivorship patterns vary with year, age, El Niño, and recapture sequence. To reinforce that there is an overall survivorship difference between the two islands, we refer to the 7 th ranked model in Table 2. The age-structured survivorship and recapture parameters design matrix for this model is as described for our best model, with two exceptions: $(i)$ there is no distinction between the two sites on each island, and (ii) adult survivorship is averaged over all years. When corrected for overdispersion ( $\hat{c}=1.39$ ), this model estimated the mean annual adult survival rate at Frederick Island $(0.80 \pm 0.02)$ to be substantially and significantly $(p=0.0001)$ higher than the survival rate at Triangle Island $(0.71 \pm 0.02)$.

\section{Differences in survival and impacts of the 1997-1998 El} Niño event

The distinction of the local survival rates for resident birds versus the local survival rates of transient birds is clearly portrayed (Fig. 3, residents; Fig. 4, transients). Survival estimates for resident adult birds were higher on Frederick Island $(0.83 \pm 0.02)$ than those on Triangle Island $(0.77 \pm$ 0.03 ) in non-El Niño years (5th-ranked model in Table 3; Fig. 3). The survival values were more similar between colonies for stage $a=2$ birds, but the uncertainty in those estimates (standard errors, SEs) was much higher because of their smaller sample sizes and probably also because of imprecision in the assignment of age on the basis of eye colour. On both colonies, survival dropped markedly for all age classes during the 1997-1998 El Niño event (Table 3, Fig. 3). Despite the marked drop in survival on both colonies in 1997-1998, the intercolony differences persisted and Triangle Island showed a lower value for survival $(0.54 \pm 0.04)$ than that on Frederick Island $(0.64 \pm 0.03)$ during the El Niño.

Local survival rates for transient birds were markedly lower than the survival rates estimated for resident birds (Figs. 3 and 4), stabilizing at 0.1-0.6 after the 1994-1995 annual interval. The predominant pattern of increasingly lower local survival rates for increasingly younger birds at Frederick Island is consistent with the concept that the youngest birds are the least likely to have established a local site residency for reproduction. The less obvious pattern at Triangle Island is arguably due to the lesser precision in assessing eye colour at Triangle Island (Appendix A). At both Frederick and Triangle islands, there is a clear pattern of decreased local survival rates after the 1994-1995 interval. This phenomenon is an anomaly of the mark-recapture protocol and arises because most resident birds at a marking site were marked during the first year of marking. During that initial year, the ratio of resident to transient birds marked tends to be higher than in all subsequent years if the survival rate of the resident birds is high, as it is. Consequently, transient birds will predominate the selection of unmarked birds for marking in subsequent years and will dominate the estimate of local survival rates for the first year postmarking in those years. Interpretation of survival for these birds should focus on the estimates of these rates that have tended to stabilized over time, as appears to have happened for our data (Fig. 4; see also Bertram et al. 2000).

\section{Discussion}

Cassin's Auklets may be impacted by oceanic conditions at their breeding grounds and (or) their wintering grounds. The survival estimates presented here reflect cumulative impacts of mortality from both the breeding and nonbreeding seasons. Our results are consistent with the interpretation that the observed intercolony differences in adult annual survival were related to differences in prey availability near the breeding colonies, whereas the parallel drop in survival at both colonies during the 1997-1998 El Niño was associated with poor prey availability on common wintering grounds. 
Table 1. Number of marked Cassin's Auklets (Ptychoramphus aleuticus) in each year contributing to the recovery matrix $(R(i,$.$) , White and Burnham (1999)) for Frederick Island and Triangle Island.$

\begin{tabular}{|c|c|c|c|c|c|c|c|c|}
\hline Occasion & Marked & $R(i,)$. & $j=1995$ & $j=1996$ & $j=1997$ & $j=1998$ & $j=1999$ & $j=2000$ \\
\hline \multicolumn{9}{|c|}{ Frederick Island $^{a}$} \\
\hline$i=1994$ & 797 & 797 & 503 & 70 & 18 & 7 & 0 & 0 \\
\hline$i=1995$ & 768 & 1271 & & 581 & 75 & 23 & 0 & 10 \\
\hline$i=1996$ & 426 & 1077 & & & 507 & 55 & 0 & 29 \\
\hline$i=1997$ & 468 & 1068 & & & & 292 & 0 & 91 \\
\hline$i=1998$ & 164 & 541 & & & & & 0 & 226 \\
\hline$i=1999$ & 0 & 0 & & & & & & 0 \\
\hline \multicolumn{9}{|c|}{ Triangle Island $^{b}$} \\
\hline$i=1994$ & 931 & 931 & 392 & 73 & 23 & 16 & 11 & 4 \\
\hline$i=1995$ & 715 & 1107 & & 272 & 78 & 38 & 8 & 5 \\
\hline$i=1996$ & 290 & 635 & & & 193 & 47 & 9 & 5 \\
\hline$i=1997$ & 506 & 800 & & & & 128 & 27 & 13 \\
\hline$i=1998$ & 342 & 571 & & & & & 113 & 39 \\
\hline$i=1999$ & 453 & 621 & & & & & & 113 \\
\hline
\end{tabular}

${ }^{a}$ Total number marked $=2623$. Effective sample size $=4754$.

${ }^{b}$ Total number marked $=3237$. Effective sample size $=4665$.

Table 2. Model rankings and ranking criteria from the computer program MARK (White and Burnham (1999) for the predominant hypotheses posed to explain Cassin's Auklet (Ptychoramphus aleuticus) survival from 1994 to 2000 at Frederick Island and Triangle Island, B.C.

\begin{tabular}{|c|c|c|c|c|c|}
\hline Model & Rank & $\Delta \mathrm{QAIC}_{\mathrm{C}}$ & $K$ & QDeviance & $\hat{\mathrm{c}}$ \\
\hline Described age structure + El Niño ${ }^{a} ; p$ grouped by eye colour within sites $(s)$ & 1 & 0 & 88 & 798.61 & 1.23 \\
\hline Described age structure; $p$ grouped by eye colour within sites $(s)$ & 2 & 2.65 & 84 & 809.47 & 1.23 \\
\hline Global model $\left(\phi_{i, g, m, a, y}, p_{i, g, m, a, y}\right)$ & 4 & 62.37 & 164 & 704.88 & 1.22 \\
\hline $\begin{array}{l}\text { Described age structure with sites }(s) \text { combined within each island and adult } \\
\text { survivorship averaged over all non-El Niño years; } p \text { grouped by eye colour } \\
\text { within sites }(s)\end{array}$ & 5 & 107.96 & 64 & 906.57 & 1.35 \\
\hline $\begin{array}{l}\text { Described age structure with sites }(s) \text { combined within each island and adult } \\
\text { survivorship averaged over all years; } p \text { grouped by eye colour within sites }(s)\end{array}$ & 7 & 148.07 & 62 & 946.67 & 1.39 \\
\hline $\begin{array}{l}\text { Described age structure; no age } a=A \text { transients; } p \text { grouped by eye colour } \\
\text { within sites }(s)\end{array}$ & 8 & 346.14 & 78 & 1165.18 & 1.89 \\
\hline
\end{tabular}

Note: Though simultaneously analysed, no parameters were shared by the Frederick Island and Triangle Island data sets. Akaike's Information Criterion corrected for over dispersion $\left(\mathrm{QAIC}_{\mathrm{c}}\right.$ ) is based on $\hat{\mathrm{c}}=1.227$ for the best (i.e., 1st-ranked) model. QDeviance, is the $\hat{\mathrm{c}}$-corrected model deviance.

${ }^{a}$ This model was the most parsimonious among a few competitive parameterizations of the effect of an El Niño year on adult Cassin's Auklet mortality.

\section{Consistent intercolony differences in adult annual survival}

Adult Cassin's Auklet annual survival on Frederick Island $(0.80 \pm 0.02)$ was consistently higher than that on Triangle Island $(0.71 \pm 0.02)$ during our study. We suggest that the adult survival on Triangle Island is lower because the birds spend both winter and summer in the California Current, whereas the Frederick Island birds move further north to spend the breeding season close to the Alaska Current in a separate oceanographic domain. Poorer feeding conditions around Triangle Island can be inferred from nestling performance data from the two colonies; chick growth and production were consistently higher on Frederick Island from 1994 to 1998 (e.g., mean nestling growth rates $\left(\mathrm{g} \cdot \mathrm{day}^{-1}\right)$ between 5 and 25 days on Frederick vs. Triangle islands were as follows by year: $1994,5.0$ vs. $4.5 ; 1995,5.2$ vs. $5.0 ; 1996,5.6$ vs. $3.6 ; 1997,5.7$ vs. $4.9 ; 1998,5.5$ vs. 3.7). (Detailed comparisons of nestling production and diet on Triangle and Frederick islands are the subject of forthcoming work.) Poor nestling growth and production on Triangle Island have been linked to the timing and availability of high quality prey, the copepod Neocalanus cristatus, in surface waters around the Triangle Island colony (Bertram et al. 2001; Hedd et al. 2002). Increased provisioning effort of seabird parents in sustained years of poor prey availability can indirectly influence adult survival based on life history models developed from theory and empirical data (Erikstad et al. 1998). Experimental manipulation of the costs of chick rearing have demonstrated significant survival costs of chick rearing in Black-legged Kittiwakes (Rissa tridactyla;. Jacobson et al. 1995; Golet et al. 1998). In addition, seasonal declines in body condition have been shown to be more pronounced in 
Fig. 3. Estimates of annual local survival from the 1 st-ranked model in Table 2 for the adult $(a=\mathrm{A}$, solid lines $)$ and intermediate $(a=$ 2, broken lines) stages of Cassin's Auklets (Ptychoramphus aleuticus) at (a) Camp Bay and (b) North Bay on Frederick Island and at $(c)$ Calamity Cove and $(d)$ West Bay on Triangle Island. These estimates apply to annual intervals later than the first year after banding to distinguish the local survival estimates for these resident Cassin's Auklets from the local survival estimates for the first-year postmarking of transient or prospecting birds, which include losses due to permanent emigration.

(a)

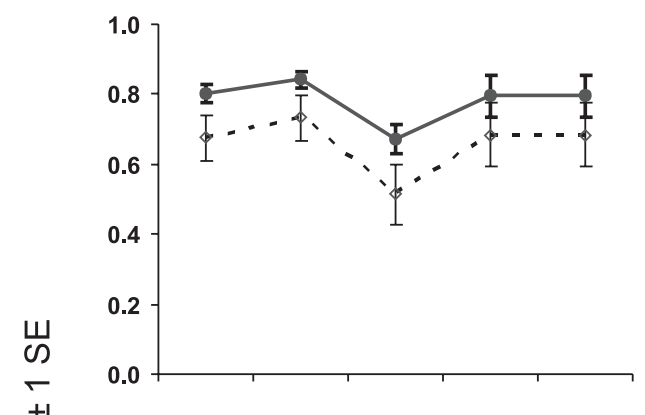

(c)

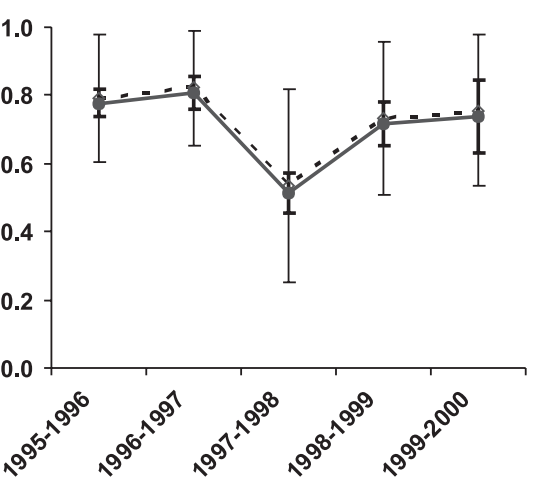

(b)

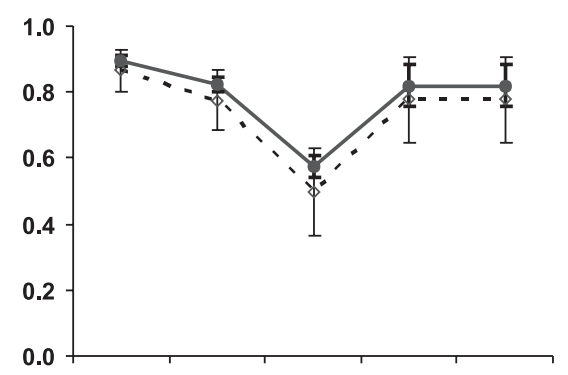

(d)

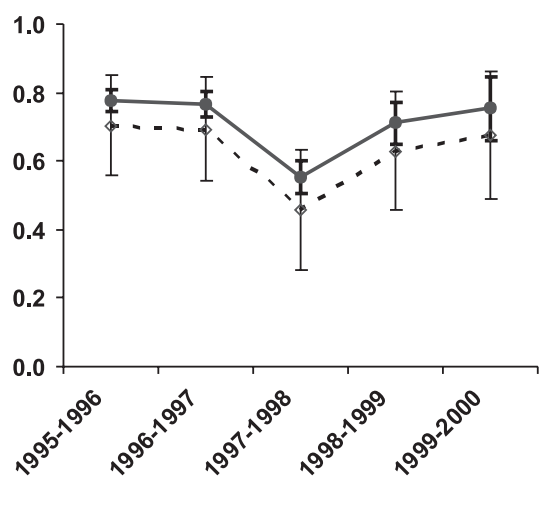

Table 3. Survivorship estimates ( \pm approximate $\hat{c}$-corrected standard errors) by age class for a single El Niño year (1997-1998) and averaged over 4 non-El Niño years (1995-1996 to 1999-2000) (5th-ranked model) and all years combined (7th-ranked model) for Cassin's Auklets (Ptychoramphus aleuticus) at Frederick Island and Triangle Island, B.C.

\begin{tabular}{|c|c|c|c|c|}
\hline \multirow[b]{2}{*}{ Age class } & \multicolumn{2}{|l|}{ Frederick Island } & \multicolumn{2}{|l|}{ Triangle Island } \\
\hline & Non-El Niño years & El Niño year & Non-El Niño years & El Niño year \\
\hline$a=1^{a}$ & $0.17 \pm 0.02$ & $0.07 \pm 0.02$ & $0.29 \pm 0.08$ & $0.13 \pm 0.05$ \\
\hline$a=2^{a}$ & $0.73 \pm 0.06$ & $0.48 \pm 0.08$ & $0.74 \pm 0.14$ & $0.51 \pm 0.19$ \\
\hline$a=A^{a}$ & $0.83 \pm 0.02$ & $0.64 \pm 0.03$ & $0.77 \pm 0.03$ & $0.54 \pm 0.04$ \\
\hline$a=A^{b}$ & \multicolumn{2}{|c|}{$0.80 \pm 0.02$} & \multicolumn{2}{|c|}{$0.71 \pm 0.02$} \\
\hline
\end{tabular}

Note: Survivorship estimates reported for ages $a=2$ and $a=A$ are based on birds which had returned to be observed their first year after being marked (Fig. 3). These birds are presumed to be resident such that local survival estimates are considered to primarily represent mortality. Local survival estimates reported for age $a=1$ include large losses due to both mortality and permanent emigration for so-called transients or prospectors (Fig. 4).

${ }^{a}$ Model ranked 5th in Table 2.

${ }^{b}$ Model ranked 7th in Table 2.

birds at "food-poor" than at "food-rich" c colonies (Kitaysky et al. 1999).

As small seabirds, Cassin's Auklets likely spend much of their time foraging to meet their energetic requirements (Furness and Ainley 1984). They have been estimated to require $67 \%$ of their body mass per day in euphausids during chick rearing (Hodum et al. 1998). Thus, it is plausible that during the years of poor reproductive performance and reduced availability of the highly profitable copepod
$N$. cristatus at Triangle Island, adult survival at that colony could be impacted through effects on body condition of breeders more than that on Frederick Island, where reproductive performance was consistently strong.

Cassin's Auklets also breed on the Farallon Islands in a colony of fewer than 20000 pairs, situated in the central California Current off northern California. Low adult survival on the Farallon Islands $(0.7 \pm 0.02$ from 1972 to 1997; Nur et al. 1998) during a period that overlaps the period of 
Fig. 4. Estimates of annual local survival from the 1 st-ranked model in Table 2 for adult ( $a=A$, solid lines), intermediate $(a=2$, dotted lines), and first-year ( $a=1$, broken lines) Cassin's Auklets (Ptychoramphus aleuticus) at $(a)$ Camp Bay and ( $b$ ) North Bay on Frederick Island and at $(c)$ Calamity Cove and $(d)$ West Bay on Triangle Island. These estimates apply only to the first year after banding to distinguish the confounding of dispersal within the local survival estimates for these transient or prospecting birds during the first-year postmarking from the survival estimates for our resident Cassin's Auklets. The figures for Frederick Island portray the tendency for younger birds to be less likely to return to the local site where they were marked when compared with older birds.

(a)

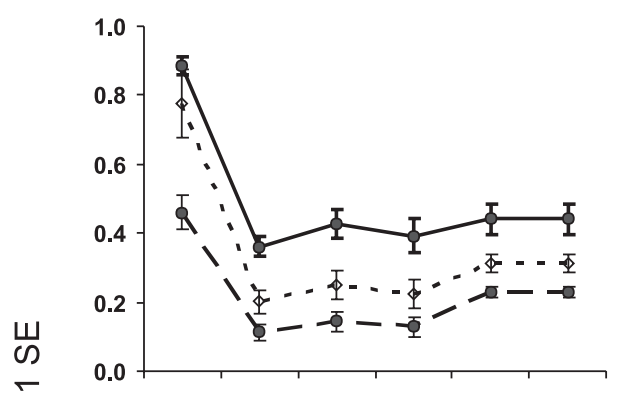

(c)

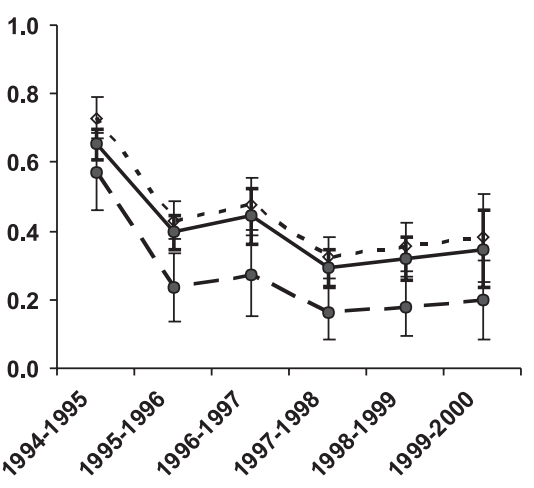

(b)

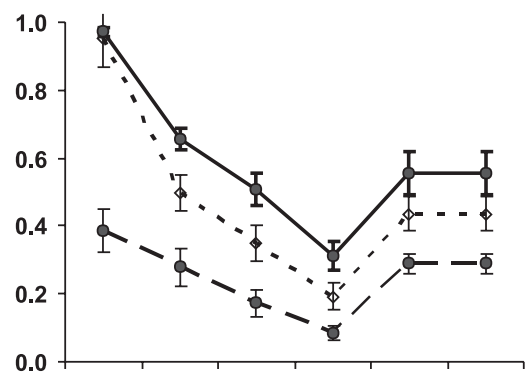

(d)

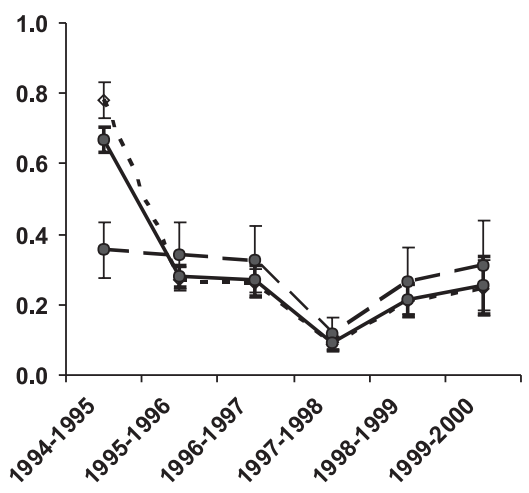

Year

our study supports the conclusion that oceanic condition, rather than colony size, is the main cause of the differences in survival between Triangle and Frederick islands. The declines of Cassin's Auklet breeding populations on the Farallon Islands (Ainley et al. 1996; Nur et al. 1998; see also Pyle 2001), on Triangle Island (Bertram et al. 2000), and in wintering seabird populations in the Californian Current (Veit et al. 1996; Oedekoven et al. 2001) are likely attributable to large-scale declines in zooplankton production in the California Current (Roemmich and McGowan 1995; McGowan et al. 1998). In contrast, there is no evidence of population decline on Frederick Island between 1980 and 1998 (M. Lemon, Canadian Wildlife Service, 5421 Robertson Rd., Delta, BC V4K 3N2, Canada, unpublished data). It is worth noting that adult annual survival of the planktivorous Least Auklet (Aethia pusilla) from Buldir Island in Alaska between 1990 and 2000 was high and averaged 0.87 over the study period (Jones et al. 2002).

The annual adult survival for Cassin's Auklet from Triangle Island was previously estimated to be 0.67 based on data from 1994 to 1997 (Bertram et al. 2000). The value reported here of 0.71 is higher and more robust because the longer time series provides a greater probability of detecting birds that were alive but not recaptured during shorter intervals.

In contrast with the consistent intercolony differences in adult survival reported in this study, survival values were similar between colonies for stage $a=2$ birds, most of which were likely not breeders (Pyle 2001). The uncertainty (SEs) in estimates for the intermediate birds was much higher because of their smaller sample sizes and probably also because of imprecision in the assignment of age on the basis of eye colour. Nonetheless, if survival was affected by provisioning effort by breeding adults, we would not necessarily expect to find a difference in survival of nonbreeders between Triangle and Frederick islands.

Independent evidence on growth and food consumption rate of planktivorous juvenile coho salmon (Oncorhynchus kisutch) from northern (north of $52^{\circ} \mathrm{N}$ ) and southern $\mathrm{BC}$ (the area west of Vancouver Island, $47^{\circ} \mathrm{N}-51^{\circ} \mathrm{N}$ ) match (Trudel et al. 2003) the patterns of seabird reproductive performance on Triangle Island (very poor) and Frederick Island (good) observed during the 1998 El Niño event. In 1998, coho salmon caught at the end of the growing season were about twofold smaller in southern BC ( 200 g) than those in northern BC ( 400 g). The lipid concentration was also lower for coho caught in southern BC in 1998. No differences in food consumption rates of coho could be detected among years (1998-2002), but changes in zooplankton community structure were much more pronounced in southern $\mathrm{BC}$ than in northern BC in 1998 (Trudel et al. 2003). The authors argued that the observed differences in juvenile coho growth rates in 1998 were likely due to differences in prey quality 
mediated through changes in zooplankton community composition. Limited availability of high quality prey in 1998 was also the explanation proposed for retarded nestling growth and mortality for Cassin's Auklet on Triangle Island in that year (Bertram et al. 2001; Hedd et al. 2002).

\section{Reduced survival during the 1997-1998 El Niño event}

A striking result of our study was that the parameterization for our best model included a uniform drop in local survival for age $a=2$ and older $(a=A)$ categories of Cassin's Auklets on both Triangle and Frederick islands during the 1997-1998 El Niño event. Consistent with that observation was a reduction in burrow occupancy on both colonies in the 1998 breeding season.

We hypothesize that this drop reflects poor winter survival in 1997-1998 caused by food shortages for Cassin's Auklets from both colonies on their wintering grounds in the California Current Ecosystem (from mid Baja California to the northern end of Vancouver Island). Ocean production and zooplankton populations were greatly reduced during the winter of 1997-1998 throughout the California Current Ecosystem. In central California, the high-nutrient, productive waters that occur in a north-south band from the coast to approximately $200 \mathrm{~km}$ offshore during cool years disappeared during the El Niño. During the 18-month period of the El Niño, nitrate in surface waters was less than $20 \%$ of normal, and new production was reduced by $68 \%$. Chavez et al. (2002) calculated the reduction in coastal California primary productivity associated with El Niño to be 50 million metric tons of carbon $\left(5 \times 10^{13} \mathrm{~g} \mathrm{C}\right)$ and further stated that "this reduction certainly had deleterious effects on zooplankton, fish and marine mammals" (Chavez et al. 2002). In BC, time series data on zooplankton biomass and community composition before, during, and immediately after the 1997-1998 El Niño event were collected off southern Vancouver Island seaward from the shelf break to $\sim 200 \mathrm{~km}$ offshore (Mackas and Galbraith 2002). During 1997-1998, zooplankton exhibited lower total biomass and shifts in community composition to more southerly fauna. The response was similar on the Oregon coast (Peterson et al. 2002; see also Mackas et al. 2004) and suggests that there was alongshore continuity from Oregon to southern BC in both oceanic forcing and zooplankton response to the recent El Niño event (Mackas and Galbraith 2002).

The similarity in the observed drop in Cassin's Auklet survival in birds from both Triangle and Frederick islands suggests that the impact was mediated in the wintering grounds and not caused by food shortages near the breeding colonies. Although evidence indicates that ocean productivity near Triangle Island was reduced during the spring and summer, no corresponding effect was evident near Frederick Island. In contrast with the situation in the California Current during the El Niño, zooplankton biomass and species composition in the Gulf of Alaska showed little interannual variation between 1997 and 2000 (Coyle and Pinchuk 2003). Furthermore, there was no drop in chick growth or fledging success in 1998 on Frederick Island (A. Harfenist, unpublished data), suggesting that prey availability was high around that colony, similarly to other years when breeding performance was also strong.
Supporting evidence for the idea that winter mortality in the California Current produced the observed survival patterns in 1997-1998 for Cassin's Auklets from Triangle and Frederick islands comes from the long-term research on the species from the Farallon Islands in central California. Analyses of time series data (1982-2002) revealed generally reduced survival during El Niño months (Sydeman and Lee 2003) and, in particular, a similar large decline in survival as observed for the BC populations during the 1997-1998 El Niño event (Abraham and Sydeman 2004; W.J. Sydeman, Point Reyes Bird Observatory, 4990 Shoreline Highway, Stinson Beach, CA 949790, USA, personal communication). Most birds that breed on the Farallon Islands are believed to winter locally in the California Current Ecosystem (Manuwal and Thoresen 1993) and thus would have been exposed to the same poor foraging conditions as were the birds from BC.

In the spring of 1998 , breeding was delayed on both Triangle and Frederick islands, perhaps because adults were in poor condition following a lean winter. The hatch dates of nestlings were 6 days later on Triangle Island in 1998 than the average date of the previous 4 years (Bertram et al. 2001) and 5 days later on Frederick Island than the average date of the previous 4 years (A. Harfenist, unpublished data). There is, however, no evidence that production at lower trophic levels was late in BC in 1998. The year 1998 was the earliest between 1994 and 1999 for the spring phytoplankton bloom peak (D. Ware, Aquatic Ecosystem Associates, 3674 Planta Road, Nanaimo, BC V9T 1M2 Canada, personal communication), and the spring peak of $N$. cristatus, a key component of the diet of BC's Cassin's Auklets (Vermeer 1981; Bertram et al. 2001), was also early off the west coast of Vancouver Island (Mackas and Galbraith 2002). Delayed breeding is also reported for Cassin's Auklets during El Niño years in the Farallon Islands (Ainley et al. 1990; Abraham and Sydeman 2004).

\section{Long-term ecosystem monitoring at sentinel colonies of planktivorous seabirds}

Our results demonstrate marked survival differences between seabird populations breeding within different oceanographic domains in BC. Our data, coupled with independent data for juvenile salmonids, indicate that $\mathrm{BC}$ is a pivotal location for detecting major oceanographic influences on upper trophic level predators. Our results on survival show that Cassin's Auklet populations performed better in the north than in the south and that both responded rapidly and strongly to the 1997-1998 El Niño event. In 1999, Cassin's Auklet breeding performance improved significantly on Triangle Island, demonstrating a rapid response to the abrupt changes in regional zooplankton communities in that year (Bertram et al. 2001; Hedd et al.2002; see also Mackas et al. 2001). We suggest that survival and reproduction parameters of planktivorous seabirds may respond more directly and rapidly than those of piscivorous seabirds to ocean climate variation because ( $i$ ) small body size and high daily energy demand increase foraging time commitments and heighten reproductive sensitivity to lean periods, (ii) the trophic connection between zooplankton and seabirds is direct, and (iii) many zooplankton prey have annual life cycles, whereas overlapping cohorts of prey fish could serve to buffer poor 
food years if birds can exploit a variety of fish age classes. In contrast with Cassin's Auklet, the larger, piscivorous Rhinoceros Auklet (Cerorhinca monocerata) from Triangle Island showed no survival impact from the 1997-1998 El Niño event (B.D. Smith, unpublished analysis). The traits of iteroparity and breeding site fidelity facilitate many years of returns from individually marked seabirds. Demographic studies on seabirds that measure adult survival, reproductive performance, and diet provide insights to marine ecosystems at local (within $100 \mathrm{~km}$ of breeding colonies) and broader scales within the migratory range during the nonbreeding season. Integration of regional fisheries and biological, oceanographic investigations with seabird time series data from sentinel colonies, such as those on Triangle Island and Frederick Island, could provide a bellwether for future ecosystem changes in the Northeast Pacific Ocean.

\section{Acknowledgements}

We thank the many volunteers and field assistants on both islands. We especially acknowledge Rob Kelly and Mark Drever on Frederick Island and crew leaders Laura Cowen, Hugh Knechtel, and John Ryder on Triangle Island for their major efforts. We thank the Canadian Coast Guard for ship and helicopter support on Triangle Island. Special thanks go to Henry Hageman of the Elnack 3, who piloted crew and supplies to Frederick Island. Ian Jones and Fred Cooke initiated the demographic study on Triangle Island. Thanks go to Connie Smith for organizing the banding data sets, reporting, and assistance with permits and to Marianne Ceh for creating the map. Gary Kaiser (Canadian Wildlife Service (CWS)) provided key logistic and technical support. BC Parks granted permission to work on the Anne Vallée Ecological Reserve, Triangle Island. The Council of Haida Nations approved the research activities on Frederick Island in Duu Guusd Tribal Park. We acknowledge the CWS, Natural Sciences and Engineering Research Council of Canada (NSERC) grants to Fred Cooke, and support funds from Centre for Wildlife Ecology at Simon Fraser University. Grants from the Nestucca Oil Spill Trust Fund and the Canadian Climate Change Action fund to D.F.B. and a collaborative United States National Oceanographic and Atmospheric Administration (US NOAA) grant in 1998 (NA77RJ0453) led by W.J. Sydeman are gratefully acknowledged.

\section{References}

Abraham, C.L., and Sydeman, W.J. 2004. Ocean climate, euphausiids and auklet nesting: inter-annual trends and variation in phenology, diet and growth of a planktivorous seabird, Ptychoramphus aleuticus. Mar. Ecol. Prog. Ser. 274: 235-250.

Adams, J., Takekawa, J.Y., and Carter, H.R. 2004. Stable foraging area and variable chick diet in Cassin's auklets (Ptychoramphus aleuticus) off southern California. Can. J. Zool. 82: 1578-1595.

Ainley, D.G., Boekelheide, R.J., Morrell, S.H., and Strong, C.S. 1990. Cassin's Auklet. In Seabird of the Farallon Islands: ecology, dynamics, and structure of an upwelling-system community. Edited by D.G. Ainley and R.J. Boekelheide. Stanford University Press, Stanford, Calif. pp. 306-338.

Ainley, D.G., Spear, L.B., and Allen, S.G. 1996. Variation in the diet of Cassin's auklet reveals spatial, seasonal, and decadal oc- currence patterns of euphausiids off California, USA. Mar. Ecol. Prog. Ser. 137: 1-10.

Barbraud, C., and Weimerskirch, H. 2001. Emperor penguins and climate change. Nature (London), 411: 183-186.

Bertram, D.F., Mackas, D.L., and McKinnell, S.M. 2001. The seasonal cycle revisited: interannual variation and ecosystem consequences. Prog. Oceanogr. 49 : 283-307.

Bertram, D.F., Jones, I.L., Cooch, E., Knechtel, H., and Cooke, F. 2000. Survival rates of Cassin's and Rhinoceros Auklets at Triangle Island, British Columbia. Condor, 102: 155-162.

Botsford, L.W., and Lawrence, C.A. 2002. Patterns of co-variability among California Current Chinook salmon, coho salmon, Dungeness crab, and physical oceanographic conditions. Prog. Oceanogr. 53: 283-305.

Boyd, I.L., and Murray, W.A. 2001. Monitoring a marine ecosystem using responses of upper trophic level predators. J. Anim. Ecol. 70: 747-760.

Boyd, W.S., Ryder, J.L., Shisko, S.G., and Bertram, D.F. 2000. Atsea foraging distributions of radio-marked Cassin's Auklets breeding at Triangle Island, British Columbia. Canadian Wildlife Service, Pacific and Yukon Region, Delta, B.C. Tech. Rep. Ser. No. 353.

Burger, A.E., and Powell, D.W. 1989. Diving depths and diet of Cassin's Auklet at Reef Island, British Columbia. Can. J. Zool. 68: $1572-1577$.

Burnham, K.P., and Anderson, D.R. 2002. Model selection and multimodel inference: a practical information-theoretic approach. Springer-Verlag, New York.

Campbell, R.W., Dawe, N.K., McTaggart-Cowan, I., Cooper, J.M., Kaiser, G.W., and McNall, M.C.E. 1990. The birds of British Columbia: Vol. II. University of British Columbia Press, Vancouver, BC.

Carl, G.C., Guiguet, C.J., and Hardy, G.A. 1951. Biology of the Scott Island Group, British Columbia. Report of the Provincial Museum, Victoria, B.C.

Chavez, F.P., Pennington, J.T., Castro, C.G., Ryan, C.G., Michisaki, R.P., Schlining, B., Walz, P., Buck, K.R., McFayden, A., and Collins, C.A. 2002. Biological and chemical consequences of the 1997-1998 El Niño in central California waters. Prog. Oceanogr. 54: 205-232.

Coyle, K.O., and Pinchuk, A.I. 2003. Annual cycle of zooplankton abundance, biomass and production on the northern Gulf of Alaska shelf, October 1997 through October 2000. Fish. Oceanogr. 12: 327-338.

Emslie, S.D., Henderson, R.P., and Ainley, D.G. 1990. Annual variation of primary moult with age and sex in Cassin's Auklet. Auk, 107: 689-695.

Erikstad, K.E., Fauchakd, P., Tveraa, T., and Steen, H. 1998. On the cost of reproduction in long-lived birds: the influence of environmental variability. Ecology, 79: 1781-1788.

Freeland, H.J., and Cummins, P.F. 2005. Argo: a new tool for environmental monitoring and assessment of the world's oceans, an example from the N.E. Pacific. Prog. Oceanogr. 64: $31-44$.

Furness, R.W., and Ainley, D.G. 1984. Threats to seabird populations presented by commercial fisheries. In Status and conservation of the worlds seabirds. Edited by J.P. Croxall, P.G.H. Evans, and R.W. Schreiber. International Council for Bird Preservation (ICBP) Tech. Rep. No. 2. pp. 701-708.

Gaston, A.J. 2003. Synchronous fluctuations of thick-billed murre (Uria lomvia) colonies in the eastern Canadian Arctic suggest population regulation in winter. Auk, 120: 362-370.

Gjerdrum, C., Vallée, A.M.J., Cassady St. Clair, C., Bertram, D.F., Ryder, J.L., and Blackburn, G.W. 2003. Tufted puffin reproduc- 
tion reveals ocean climate variability. Proc. Natl. Acad. Sci. U.S.A. 100: 9377-9382.

Golet, G.H., Irons, D.B., and Estes, J.A. 1998. Survival costs of chick rearing in black-legged kittiwakes. J. Anim. Ecol. 67: 827-841.

Hare, S.R., Mantua, N.J., and Francis, R.C. 1999. Inverse production regimes: Alaska and west coast Pacific salmon. Fisheries, 24: 6-14.

Hedd, A., Ryder, J.L., Cowen, L.L., and Bertram, D.F. 2002. Interannual variation in the diet, provisioning and growth of Cassin's Auklet at Triangle Island, British Columbia: responses to variation in ocean climate. Mar. Ecol. Prog. Ser. 229: 221-232.

Hodum, P.J., Sydeman, W.J., and Visser, G.H. 1998. Energy expenditure and food requirement of Cassin's Auklets provisioning nestlings. Condor, 100: 546-550.

Jacobson, K.-O., Erikstad, K.E., and Sæther, B.-E. 1995. An experimental study of the costs of reproduction in the kittiwake Rissa tridactyla. Ecology, 76: 1636-1642.

Jones, I.L., Hunter, F.M., and Robertson, G.J. 2002. Annual adult survival of Least Auklets (Aves, Alcidae) varies with large-scale climatic conditions of the North Pacific Ocean. Oecologia, 133: $38-44$.

Kitaysky, A.S., Wingfield, J.C., and Piatt, J.F. 1999. Dynamics of food availability, body condition, and physiological stress response in Black-legged Kittiwakes. Funct. Ecol. 13: 577-584.

Mackas, D.L., and Galbraith, M. 2002. Zooplankton community composition along the inner portion of Line P during the 19971998 El Niño event. Progr. Oceangr. 54: 423-437.

Mackas, D.L., Thompson, R.E., and Galbraith, M. 2001. Changes in the zooplankton community of the British Columbia continental margin, 1985-1999, and their covariation with oceanographic conditions. Can. J. Fish. Aquat. Sci. 58: 685-702.

Mackas, D.L., Peterson, W.T., and Zamon, J.E. 2004. Comparisons of interannual biomass of zooplankton communities along the continental margins of British Columbia and Oregon. Deep Sea Res. II, 51(6-9): 875-896.

Mantua, N. 2000. The Pacific Decadal Oscillation (PDO) [online]. Available from http://tao.atmos.washington.edu/pdo/ [accessed 5 June 2005; updated January 2000].

Mantua, N.J., and Hare, S.R. 2002. The Pacific Decadal Oscillation. J. Oceanogr. 58: 35-44.

Manuwal, D.A. 1978. Criteria for aging Cassin's Auklets. BirdBanding, 49: 157-161.

Manuwal, D.A., and Thoreson, A.C. 1993. Cassin's Auklet (Ptychoramphus aleuticus). In The birds of North America, no. 50. Edited by A. Poole and F. Gill. The Academy of Natural Sciences, Philadelphia, Penn, and The American Ornithologists' Union, Washington, D.C.

McGowan, J.A., Cayan, D.R., and Dorman, L.M. 1998. Climateocean variability and ecosystem response in the Northeast Pacific. Science (Washington, D.C.), 281: 210-217.

Nur, N., Sydeman, W.J., Hester, M., and Pyle, P. 1998. Survival in Cassin's Auklets on Southeast Farallon Island: temporal patterns, population viability, and the cost of double brooding. Pac. Seabirds, 25: 38A. [Abstr.]

Oedekoven, C., Ainley, D.G., and Spear, L.B. 2001. Variable responses of seabirds to change in marine climate: California Current 1985-1994. Mar. Ecol. Prog. Ser. 212: 265-281.

Peterson, W.T., Keister, J.E., and Feinberg, L.R. 2002. Effects of the 1997-1998 El Niño event on the hydrography and zooplankton of the central Oregon Coast. Prog. Oceanogr. 54. 381-398.

Pyle, P. 2001. Age at first breeding and natal dispersal in a declining population of Cassin's Auklet. Auk, 118: 996-1007.
Rodway, M.S. 1991.Status and conservation of breeding seabirds in British Columbia. In Seabird status and conservation: a supplement. Edited by J.P. Croxall. International Council for Bird Preservation (ICBP) Tech. Publ. No. 11. pp. 43-102.

Rodway, M.S., Lemon, M.J.F., and Summers, K.R. 1990. British Columbia seabird colony inventory: report No. 4 - Scott Islands. Census results form 1982-1989 with reference to the Nestucca oil spill. Canadian Wildlife Service, Pacific and Yukon Region, Delta, B.C. Tech. Rep. Ser. No. 86.

Rodway, M.S., Lemon, M.J.F., and Kaiser, G.W. 1994. British Columbia Seabird Colony inventory: report No.6. Major colonies on the west coast of Graham Island. Canadian Wildlife Service, Pacific and Yukon Region, Delta, B.C. Tech. Rep. Ser. No. 95.

Roemmich, D., and McGowan, J. 1995. Climate warming and the decline of zooplankton in the California Current. Science (Washington, D.C.), 267:1324-1326.

Ryder, J.L., Boyd, W.S., Shisko, S.G., and Bertram, D.F. 2001. Atsea foraging distributions of radio-marked Cassin's Auklets breeding at Triangle Island, B.C., 2000 Canadian Wildlife Service, Pacific and Yukon Region, Delta, B.C. Tech. Rep. Ser. No. 368.

Sydeman, W.J., and Lee, D.E. 2003. Comparative population biology: oceanographic correlates of seabird survival in the Southern California Current system. Pacific Seabirds, 30: 64-65. [Abstr.]

Trenbeth, K.E., and Hoar, T.J. 1996. The 1990-1995 El NinoSouthern Oscillation event: Longest on record. Geophys. Res. Lett. 23: 57-60.

Trudel, M., Zamon, J.E., Trucker, S., and Welch, D.W. 2003. Are salmon starving in the ocean? Can. Tech. Rep. Fish. Aquat. Sci. 2403: $112-118$.

Veit, R.R., Pyle, P., and McGowan, J.A. 1996. Ocean warming and long-term change in pelagic bird abundance within the California Current system. Mar. Ecol. Prog. Ser. 139:11-18.

Vermeer, K. 1981. The importance of plankton to Cassin's Auklet during breeding. J. Plankton Res. 3: 315-329.

Ware, D.M., and McFarlane, G.A. 1989. Fisheries production domains in the Northeast Pacific Ocean. In Effects of ocean variability on recruitment and an evaluation of parameters used in stock assessment models. Edited by R.J. Beamish and G.A. McFarlane. Can. Spec. Publ. Fish. Aquat. Sci. 108: 359-379.

White, G.C., and Burnham, K.P. 1999. Program MARK: survival estimation from populations of marked animals. Bird Study, 46(Suppl.): 120-138.

Wolter, K., and Timlin, M.S. 1998. Measuring the strength of ENSO events: How does 1997/1998 rank? Weather, 53: 315-324.

\section{Appendix A. Validation of eye colour as an index of maturation.}

Before subjecting our CMR data to analysis by the computer program MARK (White and Burnham 1999), we tested the veracity of eye colour to index Cassin's Auklet maturation independently for both Triangle and Frederick islands. Specifically we queried if the progression from brown-eyed, through brown-white-eyed (intermediate), to white-eyed was a consistent and reliable index of aging from first-year to second-year and then to older adult birds. We applied two approaches to investigating the relationship between eye colour and age.

In the first approach, we plotted the interannual change in eye colour for that subset of marked birds that were assessed for eye colour in any year $t$ and then again in year $t+1$ (Fig. A1). We then duplicated this approach for a subset of 
Fig. A1. Change in eye colour for individually banded and resighted Cassin's Auklets (Ptychoramphus aleuticus) between year $t$ and year $t+1(t=1994$ to 1999$)$ at Triangle and Frederick islands. The change is expressed as the percentage of individuals distributed among three possible eye colour scores in year $t+1$ conditional on their colour score in year $t$. Sample sizes in year $t$ are as follows (Triangle Island, Frederick Island): 28, 92 for brown-eyed birds; 207, 132 for brown-white-eyed (intermediate) birds; 1012, 1659 for white-eyed birds.

(a)

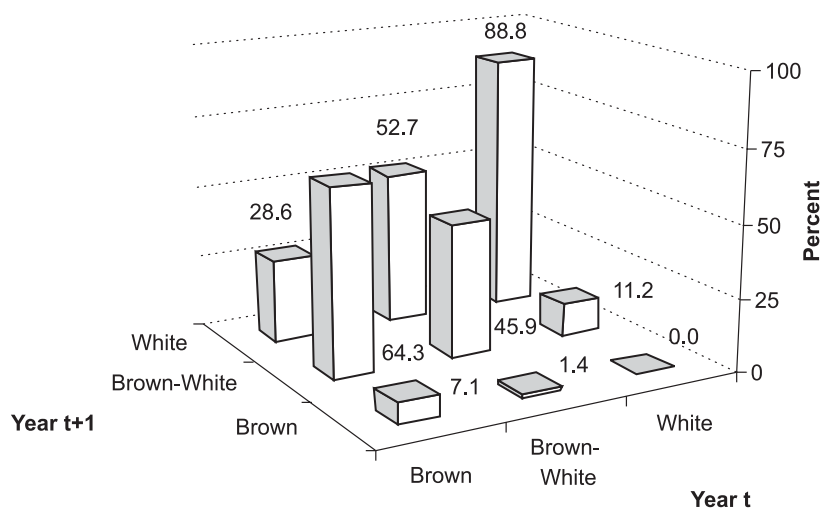

(b)

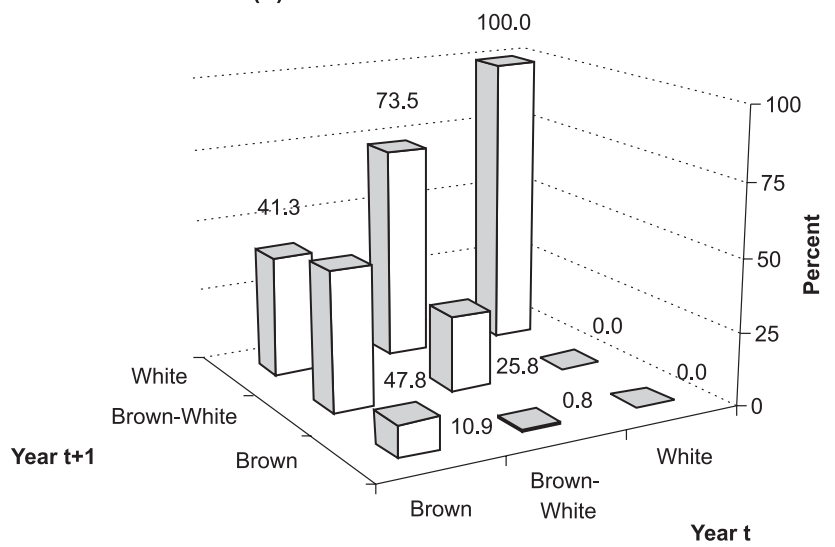

marked birds that were assessed for eye colour in any year $t$ and then again in year $t+2$ (Fig. A2).

Our second approach assessed the potential for misclassification of eye colour scores. In that approach, we plotted the percent distribution of intraannual eye colour scores for that subset of marked birds that were repeatedly assessed for eye colour within any year $t$, organized according to each eye colour score observed within the subset (Fig. A3). At Triangle Island, 1286 birds were scored more than once in a year. (At Frederick Island, this number was 293 birds.) About $90 \%$ of birds were resighted two or three times within a year, but a few were resighted as many as eight times within a year. Two tacit, yet safe, assumptions of this approach are that eye colour changed insignificantly within the roughly 2-month breeding season and that observers scoring eye type had no memory of previous scores for marked individuals they may have seen earlier in the season.
Fig. A2. Change in eye colour for individually banded and resighted Cassin's Auklets (Ptychoramphus aleuticus) between year $t$ and year $t+2(t=1994$ to 1998) at Triangle and Frederick islands. The change is expressed as the percentage of individuals distributed among three possible eye colour scores in year $t+2$ conditional on their colour score in year $t$. Sample sizes in year $t$ are as follows (Triangle Island, Frederick Island): 7, 43 for brown-eyed birds; 61, 66 for brown-white-eyed (intermediate) birds; 327, 946 for white-eyed birds

(a)

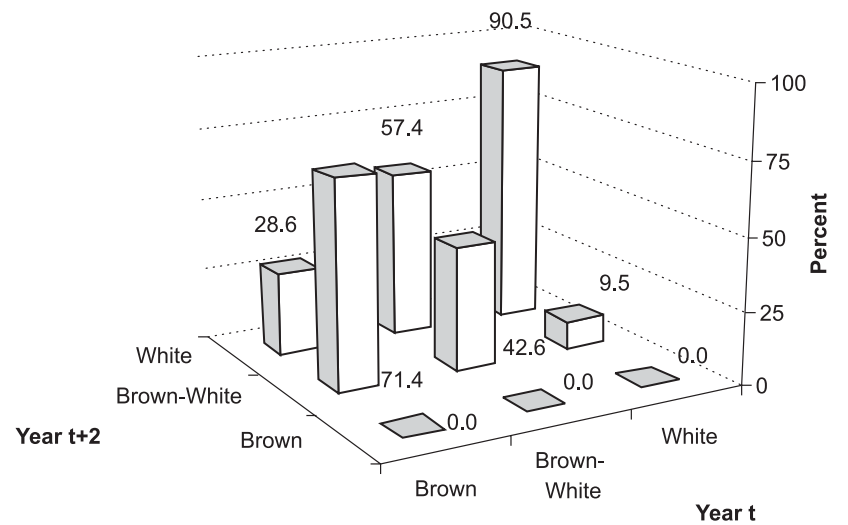

(b)

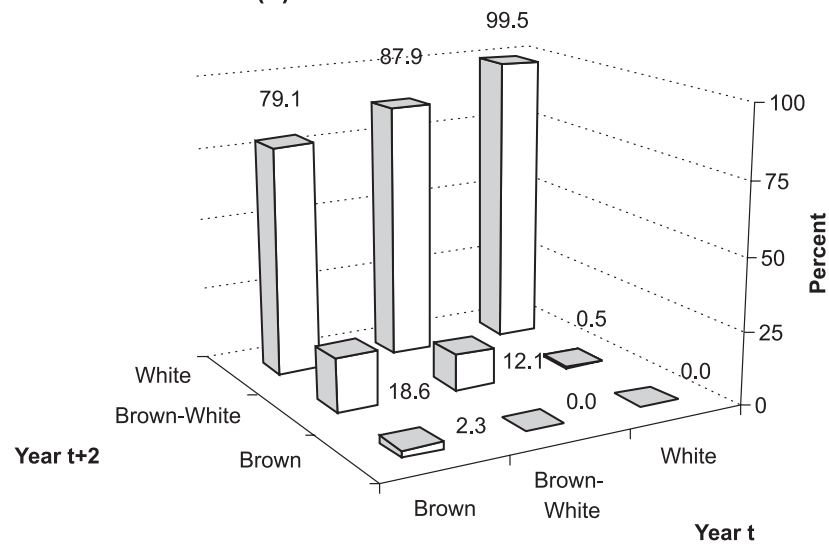

The interannual change in eye colour portrayed in Figs. A1 and A2 indicates that at both Frederick and Triangle islands, virtually all white-eyed birds remain white-eyed as they age. Though $11.2 \%$ and $9.5 \%$ of white-eyed birds at Triangle Island were assessed 1 year and 2 years later, respectively, as intermediate (Fig. A $1 a$ ), the intraseasonal evidence of Fig. A3a suggests this is probably due to observation error, especially since a retrogression in eye colour from white to intermediate seems statististically unlikely. Note that Fig. A3 demonstrates that scoring of eye colour at Frederick Island was more consistent, in general, than at Triangle Island. The largest inconsistency at Triangle Island occurs among birds scored at least once in a year as brownwhite-eyed (intermediate) birds, in that about $40 \%$ of the scores for these birds were registered as white.

A less consistent scoring of eye colour at Triangle Island than at Frederick Island is evident also for intermediate-eyed birds in year $t$ that were scored as intermediate 1 and 2 years 
Fig. A3. Variation in eye colour scores for in-season, multiplyresighted banded Cassin's Auklets (Ptychoramphus aleuticus) within any year $t(t=1994$ to 1998) at Triangle and Frederick islands. The change is expressed as the percentage of total scores distributed among three possible eye colour scores conditional on each bird being scored at least once as either brown, brownwhite (intermediate), or white in that year. Sample sizes in year $t$ are as follows (Triangle Island, Frederick Island): 76, 18 for brown-eyed birds; 844, 239 for brown-white-eyed (intermediate) birds; 3067, 514 for white-eyed birds.

(a)

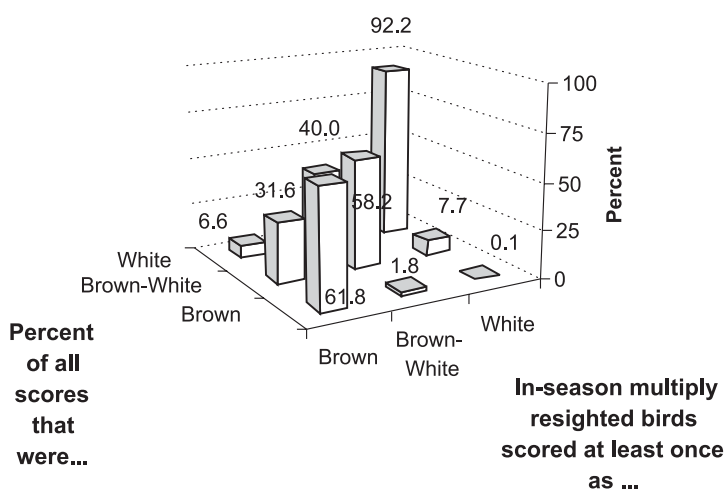

(b)

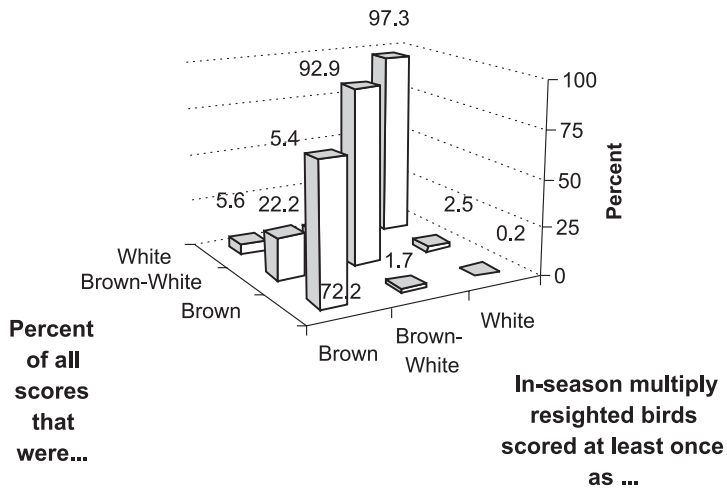

later (Figs. A1 and A2). At Triangle Island, about 40\%-45\% of intermediate-eyed birds did not change colour 1 and 2 years later, whereas at Frederick Island only $25.8 \%$ and $12.1 \%$ of intermediate birds did not change eye colour 1 and 2 years, respectively, later.

Based on the more consistent eye colour scoring at Frederick Island, our data strongly suggest that approximately 2 years are required for most $(79.1 \%$; Fig. A2) brown-eyed birds to become white-eyed. The equivalent interpretation for Triangle Island is somewhat equivocal, with only $28.6 \%$ of brown-eyed birds being scored as white-eyed 2 years later. Indeed, essentially the same progression of eye colour is observed for those Triangle Island birds scored after only a single year at large. However, if one accepts that the scoring of eye colour on Frederick Island was rigorous, and if one presumes that eye colour progression with age is unlikely to markedly differ between Cassin's Auklet populations, observer inconsistency in scoring eye colour seems the most likely explanation for the lack of eye colour discrimination of age progression (Fig. A $3 b$ ). We are comfortable with this conclusion, since eye colour scoring on Frederick Island was scored by a field crew supervised by one individual who led the CMR program. On Triangle Island, there were both more observers and higher observer turnover during the 7 years of the CMR program there.

Though observation error in scoring eye colour at Triangle Island no doubt contributes to the greater the uncertainty (relative to Frederick Island) in our estimates of survival rates obtained using the computer program MARK for Triangle Island (Table 1), our data are unequivocal that 2 years elapse between the brown-eyed and white-eyed stages for Cassin's Auklets at Frederick and Triangle islands. It follows from this conclusion, and from the support of our data (Figs. A1-A3), that our presumption that each transition from brown-eyed to the intermediate eye colour of brownwhite and then to white requires, on average, 1 year. 